\title{
DIRECTIVENESS AND ATTITUDES TOWARDS ENTREPRENEURSHIP
}

\author{
Mirosława Czerniawska \\ Department of Engineering Management, Bialystok University of Technology, \\ ul. O. St. Tarasiuka 2, 16-001 Kleosin, Poland \\ E-mail:m.czerniawska@pb.edu.pl
}

\begin{abstract}
The main aim of this research is to investigate attitudes towards entrepreneurship. It was assumed that these attitudes depend on personality traits, like directiveness. The study group consisted of 368 students. The Ray Directiveness Scale was used. Attitudes has been assessed using a set of views - five pairs of statements from publication of Morawski and a publication edited by Reykowski. Results of the research show that persons with a higher directiveness index opted for free economic competition of enterprises, reduction of the state interventionism and meritocratic emolument rules. This group also presents more positive attitudes towards business people.
\end{abstract}

Keywords: personality, directiveness, attitudes, entrepreneurship, achievements.

JEL Classification: A13.

\section{Introduction}

Transformation of the economic system in Poland, and in other Central and Eastern Europe countries, entailed the implementation of freemarket rules which on the one hand meant limiting the role of the state and social policy, while on the other hand it led to exposing the significance of one's competencies and ability to compete (Pietrzak, Balcerzak, Gajdos, \& Arendt, 2017). People stopped being 'citizens of a welfare state' and were supposed to be 'masters of their own destiny' (Wnuk-Lipiński, 1996), in other words they were supposed to exhibit their entrepreneurial skills (see Czerniawska, 2010). In the transformation period being entrepreneurial, above all, meant becoming independent from the state, including social benefits, actively striving to achieve one's own goals and, in consequence, becoming responsible for one's own existence.

Why did some manage to be 'masters of their own destiny', while others failed? Social scientists give different answers to this questions while referring to specific criteria. The aim of the research described in this particular paper is to analyse personal determinants. Personality shapes human thinking and action but also gives relative consistency to its behavior. Specific personality traits can largely determine whether people are able to be 'masters of their own destiny', and thus demonstrate entrepreneurship, persistently strive to achieve goals and organize their activity. It was assumed that directiveness, as a personality trait, is a criterion which diversifies attitudes towards entrepreneurship. Among positive attitudes were those which display acceptance of free competition among enterprises, meritocratic rules applied to the remuneration area and a limited role of the state (the role of the state is to favour the interests of the private sector and limit the welfare function). Positive attitudes towards entrepreneurship are expressed in approving the so-called business people. Why would directiveness be a personality trait favouring entrepreneurship, i.e. being 'a master of one's own fate'? In order to answer this question a psychological characteristic of this trait is necessary.

\section{Directiveness as a personality trait}

The concept of a directive personality as well as the tool to measure its occurrence level was developed by Ray (Ray, 1981a; see Brzozowski, 1997). According to the author a characteristic feature of directive people is a great need for achievements, although not in all cultures (Ray 1980c, 1981b, 1982; Ray \& Kiefl, 1984). Such need is an important, if not the most important, entrepreneurship predictor. Since publication of McClleland (1961) the need of achievement has been viewed as a factor favouring economic development of societies. In their meta-analysis of the research results, Littunen (2000), Rauch and Frese $(2000,2007)$, Collins, Hanges, and Locke 
(2004) and Okhomina (2010) indicated a relation between the need for achievements and entrepreneurship.

Directive persons are convinced that their behaviour is right (self-confidence), they impose their will on others and reveal aggressive dominance. Being dominance-oriented is understood as the level at which a given person wishes to surpass others (individual dimension) or the level at which a given person wishes that their group surpassed other groups (social dimension). Such hierarchy becomes accepted by people and reflects their values in line with the rule: 'better ones deserve more'. This rule when put into economic context is defined as meritocracy, meaning that 'you get rewarded according to your merits'. People prone to dominate are in favour of solving international conflicts in an aggressive way and incurring substantial military expenditures (Ray 1980a, 1980b; Pratto, Sidanius, Stallworth, \& Malle, 1994, as cited in Kenrick, Neuberg, \& Cialdini, 2002; Brzozowski, 1997). Supposedly aggressive domination favours effective competition and rivalry. It has been observed that men are more domination-oriented than women, in all social classes and cultures, among educated people with higher social status as well as those who manifest a great need for achievements (Ray, 1982; Sidanius et al., 1994, as cited in Kenrick et al., 2002). Nevertheless, there is a negative correlation between the inclination to dominate and social approval scale and socialising scale (Sidanius et al., 1994, as cited in Kenrick et al., 2002).

\section{Personality traits and entrepreneurship - study review}

Specialist literature does not provide any research that would refer to relation between directiveness (as a personality trait) and attitudes towards entrepreneurship, although other personality traits were subject to analysis. Sexton and Bowman (1985) highlighted the following personality traits favouring entrepreneurship: be tolerant of ambiguous situations, prefer autonomy (autonomy may be described as self-reliance, dominance, and independence), resist conformity, be interpersonally aloof yet socially adroit, enjoy risk-taking, adapt readily to change and have a low need for support. Okhomina (2010) looked into two traits: tolerance for ambiguity and internal locus of control. Korsakienè and Diskienè (2015) examined sixteen personality traits, such as self-efficacy, need for achievement, self-control, among managers and owners of small companies that have been successful. The study demonstrates positive relationships between a number of personality traits and turnover increase of small firms. Hsiao, Leeb, and Chen (2016) claimed that the internal locus of control has a positive, significant influence on entrepreneurship among managers of all levels. Such people 'believe they can control their own fate and that success and failure depend on the amount of effort invested' (Tsai, Lu, Lin, \& Ni, 2008, as cited in Hsiao et al., 2016). Meta-analysis of Suárez-Álvarez and Pedrosa (Luca \& Simo, 2016) indicates that eight personality traits are considered in the field literature as entrepreneurial: achievement motivation, risk-taking, autonomy, self-efficacy, stress tolerance, innovativeness, internal locus of control and optimism. Pundzienè and Duobienè (2006) analysed, among others, relations between the need for achievement, risk propensity and locus of control. They came to a conclusion that as far as leaders are concerned, positive correlation connections are observable between the first two traits. However, no reliable interactions of these two traits with locus of control have been found.

Chen and Lai (2010) adopted personality traits as an independent variable, environmental cognition as an intervening variable, and attitude toward entrepreneurship as a dependent variable. They found that personality traits - need for achievement, locus of control, and creative thinking - were the most important characteristics for entrepreneurship. Family, society, education and economic environment were also found to be important factors. Brandstätter (2011) conducted a meta-analysis of research results referring to personality entrepreneurship determinants. He indicated that entrepreneurship (business creation and success) depends on the intensity of such traits as: readiness for innovation, proactive personality, generalized self-efficacy, stress tolerance, need for autonomy and locus of control. Also, entrepreneurship depends on features included in the socalled Big Five, namely openness to experience, conscientiousness, extroversion, agreeableness and neuroticism. Wang, Chang, Yao, and Liang (2016) proved that self-efficacy is a factor which modifies the connection between personality traits and entrepreneurial intention. Extraversion, openness to experience, conscientiousness and agreeableness reliably predict both conviction and preparation, whereas neuroticism does not. Confirmation of such regularity may be found in the meta-analysis carried out by Zhao and Seibert (2006), Zhao, Seibert, and Lumpkin (2010). Nga 
and Shamuganathan (2010) analysed the impact of personality traits on intentions of entrepreneurial socially-oriented actions. It turned out that agreeableness positively influences all dimensions of social entrepreneurship, whereas openness exerts a positive influence on social vision, innovation and financial returns. Authors stress the fact that the 'element of appreciation of social responsibility, sustainability and character development needs to be integrated within the business education curriculum to support social entrepreneurs in realizing genuine value and impact to the causes and communities they serve'. Schmitt-Rodermund (Obschonka, Silbereisen, \& Schmitt-Rodermund, 2012) showed that the Big Five profile in relation to entrepreneurship was high in extraversion, conscientiousness and openness and low in agreeableness and neuroticism.

\section{Research problem and hypotheses}

Various interpretations of the term "entrepreneurship" can be found in the specialist literature. According to Mayer, Kortmann, Wenzler, Wetters, and Spaans (2014) it is possible to single out seven interconnected dimensions. Two of them are important from the perspective of research presented in this paper. These are:

1. Social-political-cultural value, which emphasises core capitalist values (in general sense, as opposed to political ideology), including free market, growth, innovation, creativity, prosperity, competition, private property and utility.

2. Personality traits: characteristics (values, attitude and beliefs) that make actors adhere to entrepreneurial values and prone to show enterprising behaviour, e.g. risk-taking, need for achievement.

Under the first dimension positive attitudes towards entrepreneurship are defined as the ones that are connected with accepting the rules of a free market economy and business people. The second dimension out of the indicated ones refers to entrepreneurship understood from the perspective of one's personality, as a characteristic favouring specific type of attitudes and behaviour.

In the presented research an attempt was made to answer the question whether there are any deeper psychological reasons conditioning attitudes towards entrepreneurship (dimension 1) rooted in one's personality (dimension 2). Directiveness is the personality trait selected for examination. As indicated above, directive people aim to impose their will on others and achieve superiority over them (inclination to domination). They accept a hierarchical vision of the social world and the rule "better ones deserve more". Such people are convinced about the rightness of their conduct (self-confidence), are strongly focused on themselves and individual success. Thus, they distinguish themselves by a huge need for achievements and perseverance in reaching their goals. Such personality traits make a psychological prerequisite for entrepreneurial activities. They may also favour the shaping of positive attitudes towards entrepreneurship and business people.

Assumptions made:

Hypothesis 1: People characterised by higher directiveness index expose positive attitudes towards entrepreneurship which is expressed in accepting an economic system that favours the development of individual entrepreneurship, i.e.: (1) allowing free competition between enterprises; (2) meritocratic remuneration rules; (3) the state favouring interests of the private sector; (4) limitation of the welfare function of the state. These attitudes are also expressed in (5) a positive attitude towards business people.

Hypothesis 2: People characterised by lower directiveness index wish that the state continued its welfare function and are in favour of the state interventionism. These attitudes are expressed in accepting an economic system where the state (1) helps enterprises that are not doing well; (2) impacts on the way egalitarian norms are perceived; ( 3 and 4) fulfils welfare functions for its citizens. These attitudes are also expressed in (5) a negative attitude towards business people.

\section{Method}

\subsection{Participants}

The study group consisted of 368 students, around $50 \%$ from Faculty of Pedagogy and Psychology, University of Bialystok and around 50\% from Faculty of Engineering Management, Bialystok University of Technology. On both faculties women comprised $80 \%$ of all students. Participants belonged to 20-24 age cohort (with around $90 \%$ of students aged 20 and 21). The study was anonymous.

\subsection{Measures}

Every person from the study group was vetted with a view to defining his/her:

- directiveness intensity index;

- five attitudes acceptance rate.

Traits, including directiveness, are hypothetical, basic components of personality. They make a durable characteristic of a person that is used to 
explain observed regularities and consistency of behaviour and differences between people (A. S. Reber \& E. S. Reber, 2005). Directiveness was diagnosed with the use of the Ray Directiveness Scale D-26 (Brzozowski, 1997). This tool measures the tendency to impose one's will on others (aggressive domination) and manage people using one's superior position (ordering people around). The scale includes 26 items (diagnostic answer -3 points, question mark -2 points, nondiagnostic answer -1 point). Maximum number of points participants can get is 78 , the minimum 26 .

Attitudes are sub-categories of the conviction system (Rokeach, 1973). Convictions are equated with information that people hold about themselves, the physical and social environment, ideas, legal rules, ideologies (they also cover knowledge, images and beliefs held by an individual concerning a given object). Clear-cut convictions are believed to be direct determinants of one's attitude towards an object (usually attitudes derive from convictions). Positive attitudes are shaped when most convictions associate the object with the desired traits, while negative ones when convictions about non-desirable traits dominate (Ajzen, 1996; Wosińska, 2004).
In this study attitudes were diagnosed with the use of 5 pairs of statements (see Table 1). Each pair includes two opposing views. Participants of the study were asked to express their views on these statements and select option which to a greater extent reflects convictions of an individual. Statements (or their fragments) from attitude 1 and 2 are from the work of Morawski (1991). When designing attitudes 3, 4 and 5 the publication edited by Reykowski (1993) was helpful.

\section{Results}

As indicated in the theoretical part of this paper, positive attitudes towards entrepreneurship are expressed in the acceptance of free competition among enterprises, meritocratic rules applied to the remuneration area and limited role of the state (the role of the state is to favour the interests of the private sector and limit the welfare function) as well as the acceptance of the so-called business people. The answer to the following question was searched for: Are people with higher directiveness index characterized with positive attitudes towards entrepreneurship (defined as above)?

Table 1. Directiveness and attitudes towards entrepreneurship (source: own research)

\begin{tabular}{|c|c|c|c|c|c|}
\hline No. & & Attitudes towards entrepreneurship & $\overline{\mathrm{x}}=$ & $\mathrm{s}=$ & $\begin{array}{l}\text { Results of the } \\
\text { analysis }\end{array}$ \\
\hline \multirow{2}{*}{1} & 1 & $\begin{array}{l}\text { Private sector should be completely independent from the state as } \\
\text { economic development is based on free competition between en- } \\
\text { terprises. }\end{array}$ & 57.20 & 8.13 & \multirow{2}{*}{$\begin{array}{l}\mathrm{t}=1.68 \\
\mathrm{p}=0.094\end{array}$} \\
\hline & 2 & $\begin{array}{l}\text { Economic freedom of enterprises should be limited and enter- } \\
\text { prises which are in a difficult situation should be provided with } \\
\text { help. }\end{array}$ & 55.60 & 8.81 & \\
\hline \multirow[b]{2}{*}{2} & 1 & $\begin{array}{l}\text { Salaries earned by individuals should be diversified based on their } \\
\text { qualifications and efficiency. }\end{array}$ & 58.01 & 8.03 & \multirow[b]{2}{*}{$\begin{array}{l}\mathrm{t}=4.72 \\
\mathrm{p}=0.000\end{array}$} \\
\hline & 2 & $\begin{array}{l}\text { Differences in earnings shouldn't be too big in order to avoid the } \\
\text { emergence of the rich and the poor. First of all salaries of the } \\
\text { highest paid individuals should be reduced. }\end{array}$ & 53.41 & 8.44 & \\
\hline \multirow{2}{*}{3} & 1 & $\begin{array}{l}\text { The state should favour interests of the private sector in the first } \\
\text { place. Development of the country depends on it. }\end{array}$ & 58.07 & 8.69 & \multirow{2}{*}{$\begin{aligned} \mathrm{t} & =2.09 \\
\mathrm{p} & =0.037\end{aligned}$} \\
\hline & 2 & $\begin{array}{l}\text { Above all the state should protect the living standard of the badly } \\
\text { off families and shouldn't let people to build up fortunes. }\end{array}$ & 55.94 & 8.25 & \\
\hline \multirow{2}{*}{4} & 1 & $\begin{array}{l}\text { Free national healthcare and education should be done away with. } \\
\text { The state can't afford to provide everyone with everything. }\end{array}$ & 60.56 & 9.07 & \multirow{2}{*}{$\begin{array}{l}\mathrm{t}=1.44 \\
\mathrm{p}=0.150\end{array}$} \\
\hline & 2 & $\begin{array}{l}\text { Condition necessary for a just system to exist is to guarantee each } \\
\text { citizen the right to free healthcare and education at every level. }\end{array}$ & 56.46 & 8.39 & \\
\hline \multirow{2}{*}{5} & 1 & $\begin{array}{l}\text { Business people should be regarded as heroes of our times and } \\
\text { role models of success. }\end{array}$ & 58.27 & 8.59 & \multirow{2}{*}{$\begin{array}{l}\mathrm{t}=1.80 \\
\mathrm{p}=0.072\end{array}$} \\
\hline & 2 & $\begin{array}{l}\text { The so-called businesspeople are wheeler-dealers who made a } \\
\text { fortune through swindles and circumventing the law. }\end{array}$ & 56.15 & 8.35 & \\
\hline
\end{tabular}

$\overline{\mathrm{x}}$ - arithmetic mean of directiveness indices; $\mathrm{s}$ - standard deviation; $\mathrm{t}$ - Student's $\mathrm{t}$ test result; $\mathrm{p}$ - statistical significance level. 
Data included in Table 1 and results of the statistical analysis allow to accept assumptions set forth in hypothesis 1 . Now therefore, according to persons with higher directiveness indices private sector should be completely independent from the state, while free competition between enterprises is a stimulant to the economic development (attitude 1, Table 1). They were in favour of diversifying earnings based on qualifications and efficiency (meritocratic rule) (attitude 2, Table 1). In their opinion the role of the state is to favour interests of the private sector (attitude 3, Table 1). Also, they adopted a particular attitude towards business people, namely they perceived them as "heroes of our times and role models of success" (attitude 5, Table 1). It is common knowledge that private business, free competition and meritocracy are determinants of the present economic system. They stimulate entrepreneurship and operations of the business people.

Persons with lower directiveness indices disapprovingly referred to business people ("wheeler-dealers who made a fortune through swindles and circumventing the law") (attitude 5, Table 1). In their opinion helping enterprises which are in a difficult situation is legitimate (attitude 1, Table 1). They were against excessive differences in financial status of individuals (attitude 2, Table 1) and in their opinion the state should protect the living standard of the badly off families (attitude 3 , Table 1). They were in favour of the state interventionism and the state welfare function towards citizens rather than space for individual initiative and entrepreneurship provided by the state. Obtained results allow to confirm hypothesis 2 . Being focused on the state obligations to its citizens (typical of the bygone system) is demand-based and limits the aspiration to be entrepreneurial. Nevertheless, it should be noticed that limiting freedom in the economic area, developing a welfare state and caring about the well-being of citizens constitutes the basis for the so-called social market economy.

In the case of one attitude (attitude 4, Table 1) no differences among directiveness indices were observed. In this respect statistical reasoning is invalid as only 9 out of 368 persons were in favour of rejecting free national healthcare and education in Poland.

\section{Conclusion and discussion}

Effective functioning under a new state system requires entrepreneurship which in fact is connected with accepting the rules of the free market economy and the ability to act in accordance with them. Research presented in this paper has demonstrated that positive attitudes towards entrepreneurship, understood in such a way, are rooted in the personality trait - directiveness. Directive people are willing to accept an economic system of a liberal, or even neoliberal shape. They are in favour of free competition between enterprises and meritocratic remuneration rules. In their opinion the state should take into account interests of the private sector and limit welfare functions. Also, they take a positive attitude to business people (compare hypothesis 1). Most probably such attitude results from the fact that directive people are strongly focused on Self, adopt an egocentric point of view, aim to exert control over environment, power and domination, analyse problems from the perspective of personal achievements and success.

What attitudes towards entrepreneurship appear in the minds of people characterised by lower directiveness? It turns out that they assign a much more important role to the state. They believe that the state should help enterprises and citizens who are in a difficult situation as well as supervise whether the egalitarian norms are kept. Less directive persons are sceptical of business people and perceive them negatively from the moral perspective (compare hypothesis 2). Such attitudes indicate that they accept rules of social market economy set forth in the Keynes's model. It is known that such a model favours strengthening the welfare state.

Similarly to other traits correlated with entrepreneurship (e.g. autonomy, resisting conformity, internal locus of control, enjoying risk-taking or adapting readily to change), directiveness is reflected in being focused on oneself. Being focused on Self is an expression of a specific type of mentality, i.e. individualistic mentality. Such conclusion may be drawn based on the analysis of the value preference indicators. Having applied the Rokeach approach to the value diagnosis, Czerniawska and Dolata (2005) proved that higher directiveness index is connected with greater preference for intrapersonal values, concentrated on oneself (self-respect, social recognition), that on the one hand may be of a hedonistic character (comfortable life, exciting life), and cognitive on the other hand (intellectual, imaginative, broadminded, capable). What is more, positive relations were observed between the analysed personality trait and values conditioning achieving success (a 
sense of accomplishment, ambition, independency, courage). It should be noticed that the enlisted values are of an individualistic character. They direct the focus on competencies and achievements of an individual, stimulate competition and rivalry. Competition motivates to be the best, promotes greater creativity and productivity, involvement in business and entrepreneurship (Realo, Koido, Celemans, \& Allik, 2002). Lower preference scores were given by directive persons to values referring to religiosity, egalitarianism and mental well-being (salvation, equality, inner harmony, self-control) and moral values (responsibility, being helpful, obedience, honesty, politeness, forgiveness). Values reflecting the need for integration, interpersonal and intrapersonal harmony and protecting other persons' common good are defined as collectivist. The essence of such values is that they determine allocentric convictions.

Which personality traits favour focusing on the well-being of other people and collective interest? In order to answer this question, it is necessary to quote the results of study referring to empathy. This personality trait is in favour of adopting the allocentric perspective when interpreting social phenomena. According to Czerniawska's research (2015a), empathic persons declare for state interventionism in the employment policy (ensuring work places, eliminating unemployment), more egalitarian division of effects of the developing economy and welfare state. Thus, a neoliberal version of the state under which the state is 'a night watchman' does not suit them. Empathic persons accept rules that underlie the so-called social market economy under which the interpretation of the material inequality issue and the obligation of the state to people in need is different than in neoliberalism. The fact that empathy induces people to view problems from the perspective of common good, and not only from the perspective of personal achievements and success, is reflected in the value systems. Empathic persons prefer equality, moral (love, help, honesty, politeness, forgiveness) and religious values (salvation), and prone to reject those values which are focused on themselves, i.e. hedonistic (comfortable life, pleasure, exciting life) and which contribute to individual success (ambition, independency, capability) (Czerniawska \& Dolata, 2005). Such diversity of value preference indicators suggests collective mentality whose distinctive feature is the need to integrate with other members of a group and egalitarian obligation to promote the well-being of others.
Study results presented above indicate that there are personality traits, such as directiveness for instance, which make it more probable that an individual will present positive attitudes towards entrepreneurship. There are also other personality traits, as empathy for instance, which make it more probable that an individual will focus on the issue of common good and not on personal success and achievements. Values play significant role in the process of establishing relation between personality and attitude. On the one hand values are connected with personality traits, while on the other hand they determine attitudes (Czerniawska, 2002, 2010, 2012, 2015b, 2016; Czerniawska \& Dolata, 2004, 2006). Therefore, when trying to understand attitudes towards social matters in this economic system both personal and axiological aspect should be considered.

The research results presented in this article relate to the relationship between the two psychological phenomena: personality traits and attitudes. The analysis would improve by including information on whether the directive people present entrepreneurial activities more often (and not only attitudes) and how often they are successful.

As mentioned before, values are connected with personality traits and simultaneously they determine attitudes. It is also worth describing the nature of the connections between traits and values. At the same time, it should be noted that a comprehensive personality description requires more than two traits (ie, directive and empathy). This conclusion is an inspiration for further research, in which attitudes towards entrepreneurship will be considered in the context of more traits.

During the analysis of relations between personality and social attitudes, Van Hiel, Cornelis, and Roets (2007, see Czerniawska, 2015a) exposed the significance of people's views on the social world, i.e. people, social groups and relations between them. Authors understand the idea about the world as a deeply rooted convictions, individual knowledge about the human nature and social world, to what extent this world is friendly, to what extent it is hostile, what other people are like, what types of behaviour one should expect from them and how one should react to them (Rokeach, 1960, and Duckitt \& Fisher, 2003, as cited in Van Hiel et al., 2007). In this theoretical framework, when analysing social phenomena and different perspectives on political system, one can benefit from taking into consideration the fact that the conviction that competition is inherent in social life and conditions the purpose of existence 
(namely personal well-being) is more probable to arise in the minds of people with high directiveness whereas the conviction that the social world is a place of cooperation and harmony is more likely to arise in the minds of persons with high empathy.

\section{References}

Ajzen, I. (1996). Postawy a zachowanie. In A. S. R. Manstead \& M. Hewstone (Ed.), Encyklopedia Blackwella. Psychologia spoleczna. Warszawa: Wydawnictwo Jacek Santorski \& $\mathrm{CO}$

Brandstätter, H. (2011). Personality aspects of entrepreneurship: A look at five meta-analyses. Personality and Individual Differences, 51(3), 222-230. https://doi.org/10.1016/j.paid.2010.07.007

Brzozowski, P. (1997). Skala dyrektywności Johna. J. Raya. Warszawa: Pracownia Testów Psychologicznych Polskiego Towarzystwa Psychologicznego.

Chen, Y. F., \& Lai, M. C. (2010). Factors influencing the entrepreneurial attitude of Taiwanese tertiary - level business students. Social Behavior and Personality, 38(1), 1-12. https://doi.org/10.2224/sbp.2010.38.1.1

Collins, C. J., Hanges, P., \& Locke, E. A. (2004). The relationship of need for achievement to entrepreneurship: A meta-analysis. Human Performance, 17(1), 95-117. https://doi.org/10.1207/S15327043HUP1701_5

Czerniawska, M. (2002). Empatia a system wartości. Przegląd Psychologiczny, 45(1), 7-18.

Czerniawska, M. (2010). Zmiany wartości i postaw młodzieży w okresie przeobrażeń ustrojowych - kolektywizm versus indywidualizm. Studium interdyscyplinarne. Białystok: Wydawnictwo Politechniki Białostockiej.

Czerniawska, M. (2012). Aksjologiczne uwarunkowania postaw wobec wolności ekonomicznej oraz interwencjonizmu państwa w sferze gospodarczej i socjalnej. Teraźniejszość - Człowiek-Edukacja, 57(1), 77-91.

Czerniawska, M. (2015a). Empatia a postawy wobec ustroju ekonomicznego i kwestii socjalnych. Teraźniejszość Człowiek-Edukacja, 70(2), 109-117.

Czerniawska, M. (2015b). Aksjologiczne uwarunkowania postaw studentów wobec równości praw i równości podziału. Ekonomia i Zarządzanie, 7(1), 232-253.

Czerniawska, M. (2016). Postawy „pragmatyczne” vs postawy „wrażliwości społecznej” i ich aksjologiczne uwarunkowania. Prakseologia, 158(1), 137-160.

Czerniawska, M., \& Dolata E. (2004). Makiaweliści - dlaczego ,prawie zawsze zwyciężają"?. Psychologia Rozwojowa, 9(1), 105-118.

Czerniawska, M., \& Dolata, E. (2005). Osobowościowe uwarunkowania systemów wartości. Psychologia Rozwojowa, 10(2), 123-134.

Czerniawska, M., \& Dolata, E. (2006). Systemy wartości w kontekście zmiennych osobowościowych. Psychologia Rozwojowa, 11(4), 103-114.

Duckitt, J., \& Fisher, K. (2003). The impact of social threat on worldview and ideological attitudes. Political Psychology, 24(1), 199-222. https://doi.org/10.1111/0162-895X.00322

Hsiao, C., Leeb, Y. K., \& Chen, H. H. (2016). The effects of internal locus of control on entrepreneurship: The me- diating mechanisms of social capital and human capital. The International Journal of Human Resource Management, 27(11), 1158-1172.

https://doi.org/10.1080/09585192.2015.1060511

Kenrick, D. S., Neuberg, S. L., \& Cialdini, R. B. (2002). Psychologia spoteczna. Rozwiazane tajemnice. Gdańsk: GWP.

Korsakienè, R., \& Diskienè, D. (2015). Personality traits of managers and success of firms: A case of Lithuanian SMEs. Proceedings of the European Conference on Management, Leadership (pp. 194-200). Lisbon, Portugal.

Littunen, H. (2000). Entrepreneurship and the characteristics of the entrepreneurial personality. International Journal of Entrepreneurial Behaviour \& Research, 6(6), 295-309. https://doi.org/10.1108/13552550010362741

Luca, M. R., \& Simo, A. M. (2016). Entrepreneurial traits and work satisfaction. Bulletin of the Transilvania University of Braşov, 58(1), 173-180.

Mayer, I., Kortmann, R., Wenzler, I., Wetters, Á., \& Spaans J. (2014). Game-based entrepreneurship education: Identifying enterprising personality, motivation and intention amongst engineering students. Journal of Entrepreneurship Education, 17(2), 217-244.

McClleland, D. C. (1961). The achieving society. Prinston: Van Nostrand. https://doi.org/10.1037/14359-000

Morawski, W. (1991). Przemiany ekonomiczne a społeczeństwo obywatelskie. Chapter 1 in R. Gortat (Ed.), Spoteczeństwo uczestniczace, gospodarka rynkowa, sprawiedliwość społeczna. Warszawa: Instytut Studiów Politycznych PAN.

Nga, J. K. H., \& Shamuganathan, G. (2010). The influence of personality traits and demographic factors on social entrepreneurship start up intentions. Journal of Business Ethics, 95(2), 259-282. https://doi.org/10.1007/s10551-009-0358-8

Obschonka, M., Silbereisen, R. K., \& Schmitt-Rodermund, E. (2012). Explaining entrepreneurial behavior: Dispositional personality traits, growth of personal entrepreneurial resources, and business idea generation. The Career Development Quarterly, 60(2), 178-190. https://doi.org/10.1002/j.2161-0045.2012.00015.x

Okhomina, D. A. (2010). The relationship between personality traits and entrepreneurial behavior and the moderating role of a supportive environment. International Journal of Business and Economics Perspectives, 5(1), 139-154.

Pietrzak, M. B., Balcerzak, A. P., Gajdos, A., \& Arendt, L. (2017). Entrepreneurial environment at regional level: The case of Polish path towards sustainable socio-economic development. Entrepreneurship and Sustainability Issues, 5(2), 190-203. https://doi.org/10.9770/jesi.2017.5.2(2)

Pratto, F., Sidanius, J., Stallworth, L. M., \& Malle, B. F. (1994). Social dominance orientation: A personality variable predicting social political attitudes. Journal of Personality and Scial Psychology, 67(4), 741-763. https://doi.org/10.1037/0022-3514.67.4.741

Pundzienè, A., \& Duobienè, J. (2006). CEOs' entrepreneurship in relation to reaction to organizational change. Engineering Economics, 47(2), 91-98.

Rauch, A., \& Frese, M. (2000). Psychological approach to entrepreneurial success. A general model and an overview of findings. Chapter 15 in C. L. Cooper \& I. T. Robertson (Eds.), International review of industrial and organisational psychology. Chichester: Wiley. 
Rauch, A., \& Frese, M. (2007). Let's put the person back into entrepreneurship research: A meta-analysis on the relationship between business owners' personality traits, business creation, and success. European Journal of Work and Organizational Psychology, 16(4), 353-385. https://doi.org/10.1080/13594320701595438

Ray, J. J. (1980a). Authoritarian tolerance. Journal of Social Psychology, 111(2), 303-304

Ray, J. J. (1980b). Authoritarianism and hostility. Journal of Social Psychology, 112(2), 307-308. https://doi.org/10.1080/00224545.1980.9924335

Ray, J. J. (1980c). Achievement motivation as an explantation of authoritarian behawior: Data from Australia, South Africa, California, England, and Scotland. Chapter 2 in S. Bloemfontein \& P. C. L. Heaven (Ed.), Authoritarianism: South African Studies. Africa: De Villiers.

Ray, J. J. (1981a). Authoritarianism, dominance and assertiveness. Journal of Personality Assessment, 45(4), 390-397. https://doi.org/10.1207/s15327752jpa4504_8

Ray, J. J. (1981b). Achievement motivation and authoritarianism in Manila and some Anglo-Saxon cities. Journal of Social Psychology, 115(1), 3-8. https://doi.org/10.1080/00224545.1981.9711981

Ray, J. J. (1982). Authoritarianism and achievement motivation in India. Journal of Social Psychology, 117(2), 171-182. https://doi.org/10.1080/00224545.1982.9713426

Ray, J. J., \& Kiefl, W. (1984). Authoritarianism and achievement motivation in contemporary West Germany. Journal of Social Psychology, 122(1), 3-19. https://doi.org/10.1080/00224545.1984.9713451

Realo, A., Koido, K., Celemans, E., \& Allik, J. (2002). Three components of individualism. European Journal of Personality, 16(3), 163-184. https://doi.org/10.1002/per.437

Reber, A. S., \& Reber, E. S. (2005). Stownik psychologii. Warszawa: Wydawnictwo Naukowe Scholar.

Reykowski, J. (1993). Wartości i postawy Polaków a zmiany systemowe. Warszawa: Wydawnictwo Instytutu Psychologii PAN.
Rokeach, M. (1960). The open and closed mind. New York: Basic Books.

Rokeach, M. (1973). The nature of human values. New York: Free Press.

Sexton, D. L., \& Bowman, N. (1985). The entrepreneur: A capable executive and more. Journal of Business Venturing, 1(1), 129-140. https://doi.org/10.1016/0883-9026(85)90012-6

Sidanius, J., Pratto, F., Bodo, L. (1994). Social dominance orientation and the political psychology of gender: A case of invariance? Journal of Personality and Scial Psychology, 67(6), 998-1011. https://doi.org/10.1037/0022-3514.67.6.998

Tsai, H. C., Lu, C. T., Lin, L. H., \& Ni, F. Y. (2008). The effect of locus of control on the relationships among product innovation, management accounting systems, and organizational performance. Journal of Humanities and Social Sciences, 4, 61-70.

Wang, J. H., Chang, C. C., Yao, S. N., \& Liang, C. (2016). The contribution of self-efficiency to the relationship between personality traits and entrepreneurial intention. Higher Education, 72(2), 209-224. https://doi.org/10.1007/s10734-015-9946-y

Van Hiel, A., Cornelis, I., \& Roets, A. (2007). The intervening role of social worldviews in the relationship between the five-factor model of personality and social attitudes. European Journal of Personality, 21(2), 131148. https://doi.org/10.1002/per.618

Wnuk-Lipiński, E. (1996). Demokratyczna rekonstrukcja. Z socjologii radykalnej zmiany społecznej. Warszawa: Wydawnictwo Naukowe PWN.

Wosińska, W. (2004). Psychologia życia społecznego. Gdańsk: GWP.

Zhao, H., \& Seibert, S. E. (2006). The Big Five personality dimensions and entrepreneurial status: Ameta-analytical review. Journal of Applied Psychology, 91(2), 259271. https://doi.org/10.1037/0021-9010.91.2.259

Zhao, H., Seibert, S. E., \& Lumpkin, G. T. (2010). The relationship of personality to entrepreneurial intentions and performance: A meta-analytic review. Journal of Management, 36(2), 381-404. https://doi.org/10.1177/0149206309335187 